\title{
TO TEACH OR NOT TO TEACH? THE QUESTION OF THE ACADEMIC LIBRARIAN'S PEDAGOGICAL COMPETENCIES IN THE DIGITAL AGE
}

\author{
J. Raju \\ Library and Information Studies Centre \\ University of Cape Town \\ Cape Town, South Africa \\ e-mail: jaya.raju@uct.ac.za
}

\section{ABSTRACT}

This article revisits the issue of 'librarian as teacher' in the literature and draws empirical evidence on the question of the pedagogical knowledge and skills requirements of academic librarians. A pragmativist paradigm and both quantitative and qualitative philosophical assumptions are used to address this research problem. The article reports on the outcome of content analysis of academic library job advertisements for professional library and information services positions in South Africa, supported by findings from websites of South African LIS schools and selected data from a 2015 national online survey of academic librarians in South Africa. Such an analysis, framed by Shank and Bell's $(2011,105)$ concept of 'disruptive innovations' leading to their framework for blended librarianship, is used to ascertain the pedagogical competency requirements of the academic librarian in South Africa in the current digital age. The findings include a list of pedagogical competency requirements for academic librarians and provide a critical narrative, in the context of international trends and the study's conceptual framing, on the extent to which academic librarians in South Africa meet these requirements.

Keywords: pedagogical competencies, academic librarians, LIS education, digital age, South Africa.

\section{INTRODUCTION}

Amidst a dynamic academic library environment, driven in the digital age by rapidly evolving information and communications technologies (ICTs) and changing higher education pedagogy, lies the question of the pedagogical competencies (teaching knowledge and skills) of the academic librarian. In this environment, technology has shifted the focus from the librarian as intermediary between user and information resources to the end-user being empowered to access required information directly (De Bruyn 2007; Riley-Huff and Rholes 2011). A parallel development is the transforming academy where the focus has shifted from traditional teacher-centred classroom learning to learner-centred and self-directed educational practices. In such a transformative context, working towards empowerment of the learner, the 
issue of the librarian as teacher, re-emerges. To what extent is the academic librarian 'well versed in' (Hensley 2015, 315), and puts into practice, 'the elements of educational theory, curricular learning goals and student learning assessment' (Hensley 2015, 315) in order to promote self-directed learning towards the emancipation of the end-user of information (Raju 2015, 28)? Are Library and Information Science/Studies (LIS) schools adequately preparing graduates for emerging teaching roles in academic libraries in a highly digitized higher education environment?

The notion of 'librarian as teacher' has a long history in the literature. This article revisits this issue in the literature and draws empirical evidence on the question of the pedagogical knowledge and skills requirements of academic librarians by means of content analysis of academic library job advertisements in South Africa. Such an analysis, supported by Shank and Bell's $(2011,105)$ concept of 'disruptive innovations', leading to their framework for blended librarianship, is used to address the following research question: What are the pedagogical competency requirements of the academic librarian in South Africa in the current digital age?

The research question on which this article is based, formed a secondary aspect of a wider National Research Foundation (NRF) funded research project conducted over a three-year period from 2014 to 2016. The wider study which is currently working towards the development of a national LIS professional competency index for the higher education sector in South Africa (to be published later), aims to provide a framework against which LIS employers and LIS professional employees may ascertain existing knowledge and skills as well as identify areas for further knowledge and skills acquisition.

In response to the research question relating to the pedagogical competency requirements of the academic librarian in South Africa in the current digital age, which is the focus of this article, empirical evidence was drawn from the content analysis of academic library job advertisements (2014-2016), and supported by findings from websites of LIS schools in South Africa and selected data from a 2015 national online survey of the 23 university libraries in South Africa (Raju 2016). At the time of the study there were 23 universities in South Africa with well-established academic libraries, with three more new universities in the process of being fully established.

\section{CONCEPTUAL FRAMING}

When Bell and Shank (2004) presented their 'blueprint for redefining the teaching and learning role of academic librarians', they presented a scenario of an 'increasingly competitive information environment in which the academic library no longer is the de facto resource of 
first choice for those it exists to serve' (Bell and Shank 2004, 372). In a context of ubiquitous technologically enabled innovations for information access and dissemination, and potential marginalization of the 'librarian’s role in higher education’ (Bell and Shank 2004, 373), resulting from what Shank and Bell $(2011,105)$ later term 'disruptive innovations' such as 'new computing technologies', they suggest a blended librarian framework. This framework reinvents the role of the academic library in higher education and contributes to the integration of services and practices in higher education teaching and learning processes (Bell and Shank 2004, 373).

In their updated perspective on blended librarianship, Shank and Bell $(2011,106)$ claim that the concept of blended librarianship is guided by the 'principle that librarians can and should be integral, educational partners as well as a catalyst for students' knowledge enrichment and intellectual enquiry'. Hence Bell and Shank (Bell and Shank 2004, 373; Shank and Bell $2011,107)$ define a blended librarian as 'an academic librarian who combines the traditional skill set of librarianship with the information technologist's hardware/software skills, and the instructional or educational designer's ability to apply technology appropriately in the teachinglearning process'.

This article uses Bell and Shank’s (Bell and Shank 2004; Shank and Bell 2011, 105-106) critical concepts of 'disruptive innovations' in the form of technological innovations and the blending of traditional librarian skills with information technology (IT) and pedagogical skills to address the research question: What are the pedagogical competency requirements of the academic librarian in South Africa in the current digital age? The selection of literature reviewed, which follows, was guided by these concepts.

\section{LITERATURE REVIEW}

Shank (2006, 515) conducted an exploratory study using content analysis of job advertisements/announcements in the United States of America (USA) from 1999 to 2004 for what he termed ‘the newly emerging position of Instructional Design Librarian'. He explains, what many studies globally (Chiware 2007; Mathews and Pardue 2009; Riley-Huff and Rholes 2011; Shongwe 2015; Musangi 2015; Baro and Godfrey 2015, and many more) have revealed: the increase in demand for computer and IT skills in LIS, many of which are traditional library services now being delivered with the use of evolving digital technologies, thus constituting the ‘disruptive innovations’ referred to by Shank and Bell $(2011,105)$. But Shank $(2006,516)$ adds that the 'increase in the number of library position announcements requiring computer skills over the past several decades is mirrored by an increase in job ads that seek instruction skills'. 
He elaborates that these instructional positions include some of the more traditional roles of academic librarians such as reference work, user instruction and collection development but adds the 'roles of both instructional designer and instructional [or educational] technologist' (Shank 2006, 515). Shank’s study (2006) concludes that librarians with both technology and pedagogical skills are becoming critical to a digitized academic library environment, characterized by Shank and Bell’s $(2011,105)$ 'disruptive innovations’.

In this context of 'disruptive innovations' in the form of rapidly evolving ICTs impacting academic library services, Miller (2007, 202, 207) researches 'blending in educational technology' in twenty first century librarianship. He is critical of LIS schools' over-emphasis on IT skills and neglect of instructional design and teaching and learning theories, arguing that 'understanding of new "pedagogical technology” is critical' (Miller 2007, 207). He refers to Bell and Shank's $(2004,373)$ lament that 'many members of our [LIS] profession are woefully deficient in their knowledge of how learning takes place, how structures for effective learning are designed and how learning outcomes are assessed'. Miller (2007) argues that LIS professional preparation needs to develop pedagogical knowledge and skills in teaching, using technology in order to empower the end-user of information to navigate the complex digital information terrain. Sinclair (2009, 504), too, uses Bell and Shank’s (Bell and Shank 2004; Shank and Bell 2011) blended approach to argue for a response to the 'marginalization of the academic library' in the face of 'the growing popularity of [disruptive innovations such as] learning management systems, eBooks, eJournals, online textbooks, Amazon, Google and a host of other competing commercial services'. Using the case of the learning commons, Sinclair (2009, 504-505) argues for blending traditional LIS skills and values 'with the latest developments in information technology and instructional design' to make the learning commons in the library 'an extension of the classroom experience ... in order to meet the needs of the $21^{\text {st }}$-century learner'. The big question is: Is the academic librarian in a position to exercise these pedagogical skills?

Walter (2008) used semi-structured interviews with academic librarians in the USA to explore the extent to which academic librarians view themselves as teachers and the ways in which teaching has become a feature of the academic librarian's professional identity. For over a century, academic librarians have been involved in instructing students in one form or another; but in recent decades changes in higher education have contributed to an increasing focus on the role of the librarian as teacher (Walter 2008, 52). In a context of rapid ICT advancements, dramatic changes in scholarly communication and higher education pedagogy, and the resulting adoption of innovative academic library staffing models, Walter (2008, 51-52) explains that 
academic libraries are making concerted efforts to integrate their services into the broader teaching and learning missions of their universities. In doing so academic librarians have become 'increasingly responsible for a variety of activities directly related to teaching and learning'. He adds 'that the scope of these responsibilities has expanded in recent years to encompass instruction delivered in the library, across the campus, and in online learning environments' (Walter (2008, 52). The personal narratives of academic librarians in Walter's study $(2008,51,56,61)$ revealed that teaching is indeed a 'core focus' of their work and that the amount of professional time and effort contributing to teaching responsibilities 'has increased significantly'; and that they 'identified strongly with the role of the librarian as teacher'. However, these personal narratives suggest that while academic librarians are increasingly called on to 'act (and to think of themselves) as teachers', they are provided with very little training on how to teach in their professional education. Walter $(2008,60)$ cogently points out that while the teaching responsibilities of academic librarians, many of whom are 'unceremoniously thrust into the classroom', are not likely to diminish in the current digital age's higher education environment, 'simple mastery of basic instructional competencies, will not help librarians to develop the sort of teacher identity [and ensuing credibility from students, academic staff, and other university constituencies] that research in teacher education suggests is important to their ongoing professional development'. In other words, sound pedagogical foundations in teaching and learning in the professional preparation of academic librarians, are required.

The literature reflects criticism of LIS schools for their neglect of this area in their professional preparation of LIS graduates for the academic library work place. Westbrock and Fabian (2010, 569) asked: 'Where are librarians learning the skills necessary to be competent and effective teachers? Are library schools preparing future librarians for their roles as classroom instructors, or are librarians primarily learning these skills on the job through trial and error?' As early as 1993 Shonrock and Mulder (cited in Westbrock and Fabian 2010, 569) revealed that librarians were learning instructional skills, which they would have preferred to have acquired in LIS schools, on the job. Westbrock and Fabian's 2010 follow-up study which surveyed academic librarians using a questionnaire based on the ACRL's (Association of College and Research Libraries 2008) revised standards for proficiencies for instruction librarians, showed some improvement in this area by LIS schools although schools still had more to do. Academic librarians, while showing a strong preference for acquiring most of their instruction proficiencies in LIS schools, also indicated a strong willingness to learn teaching skills on the job. Hall $(2013,34)$ surveyed academic librarians as employers and while he found 
'increasing primacy of instruction in public service jobs in academic libraries', he found it disconcerting that employers relied on observation and on-the-job-training as methods for 'new hires to get the training they need for instruction'. Hall $(2013,34)$ questions 'how much is lost by having an instruction librarian who is not at least grounded in the rudiments of pedagogy' grounding that should come from LIS schools during professional preparation.

Davies-Hoffman, Alvarez, Costello and Emerson (2013, 9) complain that despite criticisms in the literature 'for over thirty years', there is still a 'lack of pedagogical training for new librarians'. This lack persists in the context of the growing importance of information literacy (Davies-Hoffman et al. 2013, 9) and a complex digital environment, which according to Westbrock and Fabian (2010, 569), requires librarians to teach students the skills necessary 'to navigate, understand and assess this vast world of information'. Davies-Hoffman et al. (2013) cite global studies to show how infrequently pedagogical training is offered in LIS schools as a required core course; it is often embedded as a minor inclusion in a broader reference services course. Where there has been growth in instruction courses these have largely been electives. Davies-Hoffman et al. (2013, 22) present an independent information literacy pedagogy training initiative involving programme content, organization, funding, assessment methods and learning outcomes. They argue that all LIS schools should equip librarians with the knowledge and skills to teach in the current digital information landscape - that is, to blend traditional librarian skills with pedagogical skills in response to the 'disruptive innovations' of digital information technologies of Shank and Bell $(2011,105)$.

Brecher and Klipfel (2014, 43, 46) review recent literature showing the continuing 'troubling disconnect between ... the importance of teaching and information literacy instruction ... and ... apparent lack of education training many librarians receive during library school'. They emphasize that in today's academic library environment 'an understanding of how students learn is critical' and hence a 'basic grounding in the theory and psychology of how students learn' is an important priority for instructional work. They suggest several practical strategies that practising professionals may adopt to fill these lacuna in LIS education and to deepen understanding of educational theory and practice: undertaking coursework beyond that of LIS schools in Education; participating in blogs by instructional librarians and in relevant massive open online courses (MOOCS); reading books on educational theory and practice, amongst others. Beyond North America which dominates this literature, Raju's (2015) study on South African LIS education responses to a changing information landscape embraced a heutagogical approach which places responsibility for learning on students. It focuses on their developing self-directive information searching competencies. Raju $(2015,22,26,28)$ found 
the following: interest from 83 per cent of employers (ascertained through content analysis of academic library job advertisements) in hiring librarians with teaching/instruction skills as opposed to a mere 6 per cent response to this need from LIS schools (ascertained via a survey of LIS school heads and school websites). Raju urges LIS schools in South Africa to give 'urgent attention' to 'teaching and learning skills for information professionals'.

Corrall (2010, np), using a case study approach, explains from a LIS school perspective that 'library education has been a contentious issue for several decades. The problems identified are not easily resolved as there are complex forces at work, multiple constituencies to satisfy and competing values to reconcile'. She focusses on the 'blurring of boundaries between professions and the growth in hybrid and blended information-based roles' in what she refers to as 'complex pluralist information environments awaiting our graduates'. This resonates with Bell and Shank's (2004) and Shank and Bell's (2011) conceptualization of the academic librarian blending the traditional skills of librarianship with the information technologist's hardware/software skills, and the educational designer's ability to apply technology appropriately to teaching and learning. These are examples of efforts by twenty first century academic libraries to integrate their services into the broader teaching and learning missions and processes of their universities in response to the 'disruptive innovations' - digital technologies' impact on higher education.

According to Walter $(2008,57)$, continuing professional development 'remains a critical resource for librarians learning to teach' - these have taken the form of opportunities provided by professional LIS associations such as the American Library Association (ALA) or the ACRL, workshops, conferences, on-the-job-training, consultations with academic colleagues and independent study. Westbrock and Fabian $(2010,573)$ explain that in response to this gap in formal LIS education 'librarians themselves have not ignored the important shift that has taken place in terms of their roles as educators on campuses' with some academic libraries 'developing in-house professional development programs that address the need to teach librarians those pedagogical skills they missed in graduate school'. However, Hensley’s (2015, 315) conjecture is that while these professional development opportunities emerge in various academic libraries, ‘this effort simply isn’t broad or deep enough to adequately train librarians for the reality of classroom needs', a point also made by Hall (2013). Hensley $(2015,321)$ uses a case study of an instruction librarian working with LIS academics to co-create an information literacy instruction course for LIS students, in order to respond to Walter's $(2008,53)$ question that while 'teaching skills are clearly recognized as important to the professional work of the academic librarian ... to what degree is 'teacher identity' a recognized aspect of the broader 
professional identity of academic librarians?'. Hensley $(2015,321)$ demonstrates the need for academic librarians to build teaching collaborations with academic colleagues to 'elevate faculty members' perception of librarians as teachers', stating that 'librarians will only realize their potential as true collaborators with teaching faculty when they are able to hone in and express their full "teacher identity"'.

In summary, Shank and Bell’s $(2011,105)$ 'disruptive innovations' has led to an increase in demand for ICT skills in contemporary academic libraries. This in turn has created an increased need for pedagogical skills on the part of academic librarians in order for them to empower students with knowledge and skills to navigate a complex digital information terrain. Hence librarians with both technology and pedagogical skills have become increasingly critical in a digitized academic library environment which resonates with Bell and Shank's concept of the blended librarian requiring cross-disciplinary competencies in a pluralist information environment. In the troubling context of a disconnect between the increasing importance of pedagogical skills in public service academic library positions and the response from LIS schools to this skills demand, academic librarians have had to resort to continuing professional development (CPD) to prepare themselves for teaching roles increasingly thrust upon them in a technology-driven higher education information environment. Much more work needs to be done both on the part of practising instruction librarians and LIS schools to enable academic librarians to develop a confident teacher identity, and credibility as teachers with students, academics and other university constituencies. The literature reviewed for this study suggests key pedagogical knowledge and skills are required for the academic librarian to fulfil a teaching role. These are captured in Table 1. This study used this list of competencies as a base, and proceeded to craft a methodology responding to the research question: What are the pedagogical competency requirements of the academic librarian in South Africa in the current digital age?

Table 1: Key pedagogical competencies for academic librarians from the literature

\begin{tabular}{|l|}
\hline Key pedagogical knowledge and skills \\
\hline Assessment of student learning \\
\hline Classroom management \\
\hline Designing learning material \\
\hline Educational technology \\
\hline Instructional design \\
\hline Lesson planning \\
\hline Online instruction \\
\hline Pedagogical and learning theory and styles \\
\hline Programme management \\
\hline Public speaking, communication and presentation skills \\
\hline Reflective practice/critical reflection on teaching \\
\hline
\end{tabular}




\begin{tabular}{|l|}
\hline Key pedagogical knowledge and skills \\
\hline Research instruction and support \\
\hline Teaching methods \\
\hline
\end{tabular}

\section{METHODOLOGY}

A pragmativist paradigm, which allows for the use of both quantitative and qualitative philosophical assumptions in a mixed methods research approach (Biesta 2010, 95-97; Punch 2014, 304; Creswell 2014, 15-16), was employed to respond to the research question being addressed in this article (What are the pedagogical competency requirements of the academic librarian in South Africa in the current digital age?). In response to this research question content analysis of academic library job advertisements in South Africa for the period 20142016 was conducted. Content analysis is a commonly used descriptive technique for analyzing the content of a document to discover features and trends (Neuman 2006, 44). Content analysis of job advertisements is a well-established method of researching work place requirements in a particular sector (Orme 2008, 620, 623).

A total of 108 advertisements were sourced using the Mail \& Guardian weekly newspaper and LiasaOnline and related listservs of the Library and Information Association of South Africa (LIASA), as well as university websites referred to by the Mail \& Guardian or LiasaOnline and its related listservs. These sources contributed to an exhaustive search of all professional position (requiring a professional LIS qualification) advertisements. This report includes job advertisements collected from January 2014 up to September 2016 (108 in total). For positions in the 23 South African universities with well-established academic libraries at the time of the study, thirty-two (32) advertisements were sourced for 2014, 31 for 2015 and, 45 for the 9-month period of January to September 2016.

To establish the pedagogical competency requirements of the academic librarian in South Africa in the current digital age, a baseline list of pedagogical knowledge and skills was gleaned from the international literature (see Table 1). This list allowed for data mining as a means of content analysis of academic library job advertisements. Bell and Shank’s (Bell and Shank 2004; Shank and Bell 2011, 105-106) concepts of 'disruptive innovations' and the consequent need for blending of traditional librarian skills with IT and pedagogical skills informed the compilation of a list of teaching and learning competencies based on the list gleaned from the literature. The 108 advertisements were reviewed qualitatively with the objective of iteratively adjusting the list of competencies based on the literature to reflect job requirements in the advertisements sourced for this study accurately. Only minor adjustments were necessary, for example, dealing with synonyms, overlap in terminology, etc. However, the qualitative 
reviewing was critical in leading to the decision to cluster related competencies under generic labels for more meaningful analysis in response to the research problem. Owing to the very specific nature of the data being mined, the aspects of the job advertisements that were focused on for content analysis purposes were job titles, descriptions, requirements, responsibilities and recommendations. The researcher was careful not to duplicate counts which is a danger when multiple areas of an advert are being sourced for data. Further, as a result of the highly specific nature of the skills sets that needed to be mined (pedagogical knowledge and skills), the researcher did not consider it necessary to use data mining software, for example Provalis QDA Miner, as in previous studies (Raju 2016). The relatively small size of the data set did not warrant software application and further, manual data mining allowed for the capture of finer nuances in the data, such as overlap in skills sets and clustering of related competencies, which could have been lost using a data mining software application. The 108 advertisements were reviewed quantitatively, with simple coding (X) to determine frequency counts and relative frequency percentages for the identified knowledge and skills sets. This quantitative analysis was captured in Microsoft Excel and reproduced in Microsoft Word for the generation of Table 2 and subsequent collation of pedagogical competency requirements in Figure 1.

The teaching and learning knowledge skills list generated via quantitative data mining of job advertisements (main source of data for this report) was triangulated qualitatively, where appropriate, with selected findings from the national online questionnaire survey, conducted in 2015 as part of the wider national LIS professional competency index research project mentioned in the Introduction. While some aspects of this generic survey have been reported in Raju (2016), other aspects are being used to contribute to the higher education LIS competency index being developed. Senior LIS professionals in 23 of South Africa's 26 university libraries were targeted (three newly established universities were excluded due to their libraries still being established for these institutions). Twenty-two of the 23 universities responded to the survey. There were between 5 and 15 responses from each of these university libraries. The Library Directors were asked to select senior LIS professional staff (e.g. Senior Librarians) to complete the questionnaire. Of the 207 potential respondents identified by the university libraries to whom an online questionnaire using SurveyMonkey was sent, 140 responded (68\% return rate). Those findings from this generic survey that speak to the research problem of the pedagogical competency requirements of the academic librarian in South Africa in the current digital age, are discussed (and reported for the first time) in the Findings and Discussion Section of this article. Further, for a 'more complete understanding' of the aspect of the academic library world being investigated (Creswell 2014, 4), quantitative data from the 
job advertisement analysis were also compared with qualitative findings from the curriculum pages of websites of South African LIS schools. This too is reported in the Findings and Discussion Section. Findings in response to the research question seeking to ascertain the pedagogical competency requirements of the academic librarian in South Africa in the current digital age in the context of Bell and Shank’s (Bell and Shank 2004; Shank and Bell 2011, 105106) concepts of 'disruptive innovations' and blending of cross-disciplinary competencies in a highly digitized academic library environment, are presented and discussed in the next section.

\section{FINDINGS AND DISCUSSION}

Table 2 captures findings from the content analysis of the 108 job advertisements. It is immediately evident that 'disruptive innovations' in the form of evolving digital technologies (Bell and Shank 2004; Shank and Bell 2011, 105) appear to have led to an increase in the instructional role of the academic librarian. The frequency count for instruction and training related (generic, library related and research related) knowledge and skills, in the 108 job advertisements analyzed for the period 2014-2016, totaled 136 which represents a significant relative frequency percentage of almost 45 per cent. This is in line with similar trends reported in the international literature (Shank 2006; Miller 2007; Walter 2008; Hall 2013; Raju 2015, amongst many others). This trend is also supported by the following findings in the 2015 online survey of university libraries in South Africa: When senior librarians were asked to rate the importance of teaching and learning skills to their academic library environments, 89 per cent of the 102 respondents to this item rated this skills set as being important or very important. Further, in a range of weighted average or mean calculations from 3.82 to 4.66 for an item with 115 respondents, Teaching and learning knowledge and skills become necessary for LIS professionals to teach higher education users how to navigate the digital information terrain scored 4.64 - this higher end mean score is an indication of the importance senior librarian respondents attached to teaching and learning knowledge and skills for the digitized academic library environment.

In Table 2 research related knowledge and skills on the part of academic librarians in the form of sharing research methodology skills and providing research support and instruction to postgraduate students and researchers (e.g. bibliographic referencing management; bibliometrics and altmetrics for research impact reporting; data management planning), notched up a frequency count of 48 (15.79\%). This is an indication that teaching or instructional work in the current digital age is not only confined to information literacy instruction for undergraduates but is offered to postgraduates as well. There was also support for this finding 
in the 2015 online survey of university libraries in South Africa when senior librarians were asked to rate the importance of research related services and accompanying skills requirements to their academic library environments. Research support librarianship, Research data services and Research skills enjoyed high mean scores of 4.66, 4.40 and 4.40, respectively.

In Table 2 generic communication skills (verbal and written, interpersonal and presentation skills) received a frequency count of 140 - almost 50 per cent of the total frequency count of 304. It is obvious that these generic skills are critical to a teaching or instructional role, hence it is not surprising that job advertisements requiring an instructional role would prioritize this skills set. In the 2015 online survey, 90 per cent and 92 per cent of the 102 senior librarians who responded to the item considered Communication (written and oral) skills and Interpersonal skills, respectively, as being important or very important to their academic libraries. The literature, too, reports studies showing the primacy of this skills set in librarian teaching and instructional roles: 'Not surprisingly, $80 \%$ of the announcements required candidates to possess excellent communication and/or interpersonal skills’ (Shank 2006, 520); 'The categories with the highest means were Presentation Skills ...' (Westbrock and Fabian 2010, 578); 'Library employers are seeking professionals who ... are comfortable with presentations and public speaking' (Saunders 2015, 17).

Table 2: Pedagogical competency requirements of the academic librarian in the digital higher education environment

\begin{tabular}{|c|c|c|}
\hline Pedagogical competency requirements & Freq. & $\begin{array}{l}\text { Relat. } \\
\text { freq. (\%) }\end{array}$ \\
\hline \multicolumn{3}{|l|}{ Generic communication skills } \\
\hline Communication skills (written and verbal) & 61 & 20.07 \\
\hline Interpersonal skills & 55 & 18.09 \\
\hline Presentation skills & 24 & 7.89 \\
\hline \multirow[t]{2}{*}{ Public speaking } & 0 & 0 \\
\hline & 140 & 46.05 \\
\hline \multicolumn{3}{|l|}{ Library instruction and training (Bibliographic instruction) knowledge and skills } \\
\hline User education & 7 & 2.30 \\
\hline User instruction & 13 & 4.28 \\
\hline Information literacy instruction & 11 & 3.62 \\
\hline $\begin{array}{l}\text { Collaborate with academic staff to develop subject related information literacy } \\
\text { programmes }\end{array}$ & 6 & 1.97 \\
\hline Reference experience & 1 & 0.33 \\
\hline \multirow[t]{2}{*}{ User-interface design skills } & 1 & 0.33 \\
\hline & 39 & 12.83 \\
\hline \multicolumn{3}{|l|}{ Generic instruction and training skills } \\
\hline Training and developing staff & 13 & 4.28 \\
\hline Teaching/Training and coaching/mentoring skills & 35 & 11.51 \\
\hline \multirow[t]{2}{*}{ Facilitation skills } & 1 & 0.33 \\
\hline & 49 & 16.12 \\
\hline \multicolumn{3}{|l|}{ Pedagogical knowledge and skills } \\
\hline Instructional design (lesson plans; learner-centred content; learning outcomes) & 9 & 2.96 \\
\hline Lesson planning & 0 & 0 \\
\hline Assessment of student learning & 3 & 0.99 \\
\hline Assessment methods & 0 & 0 \\
\hline Teaching methods & 1 & 0.33 \\
\hline
\end{tabular}




\begin{tabular}{|c|c|c|}
\hline Pedagogical competency requirements & Freq. & $\begin{array}{l}\text { Relat. } \\
\text { freq. (\%) }\end{array}$ \\
\hline Learning theories & 0 & 0 \\
\hline Learning styles & 0 & 0 \\
\hline Programme management & 0 & 0 \\
\hline Classroom management & 0 & 0 \\
\hline Creating instructional material & 5 & 1.64 \\
\hline Instruction related experience & 0 & 0 \\
\hline \multirow[t]{2}{*}{ Reflective practice/Critical reflection of teaching } & 0 & 0 \\
\hline & 18 & 5.92 \\
\hline \multicolumn{3}{|l|}{ Research related knowledge and skills } \\
\hline Research instruction/training & 3 & 0.99 \\
\hline Research skills & 16 & 5.26 \\
\hline \multirow[t]{2}{*}{ Research support } & 29 & 9.54 \\
\hline & 48 & 15.79 \\
\hline \multicolumn{3}{|c|}{$\begin{array}{l}\text { Blending LIS skills with IT skills and pedagogical skills (Bell and Shank 2004; Shank } \\
\text { and Bell 2011) }\end{array}$} \\
\hline Educational technology skills & 2 & 0.66 \\
\hline Instructional technology skills & 1 & 0.33 \\
\hline Research related technology skills & 1 & 0.33 \\
\hline Developing online/web resources/tools (e.g. modules, materials, guides) & 6 & 1.97 \\
\hline Online courseware skills (e.g. CMS, LMS) & 0 & 0 \\
\hline \multirow[t]{2}{*}{ Multimedia applications to learning } & 0 & 0 \\
\hline & 10 & 3.29 \\
\hline TOTAL & 304 & 100 \\
\hline
\end{tabular}

Table 2, however, shows very meagre (sometimes nil) frequency counts in the cluster labelled Pedagogical knowledge and skills, translating into a relative frequency percentage of just 5.92 per cent. This cluster, as may be observed from Table 2 and Figure 1, includes knowledge and skills that embrace the pedagogical foundations of teaching and learning. The literature is very clear that while studies have shown an increasing need for teaching skills in the digital age academic library environment, many (Miller 2007; Walter 2008; Hall 2013; Hensley 2015) have questioned whether academic librarians have the necessary grounding in the 'rudiments of pedagogy' (Hall 2013, 14) to take on these roles seriously. Are they simply being 'unceremoniously thrust into the classroom' (Walter 2008, 60) to do the best they can with what they have learnt on the job. The findings Table 2 are a reflection of the latter. The fact that the 108 job advertisements analyzed showed a preponderance of only generic level instruction and training knowledge and skills requirements and did not reflect deeper level pedagogical knowledge and skills such as lesson planning, assessment methods, teaching methods, learning theories, learning styles, classroom management, reflective practice in teaching, etc. is an indication of the absence of this level of pedagogical knowledge in the academic library work place. This finding emerges despite the fact that trends articulated in this article show the need for such knowledge and skills. In view of the ongoing lament in the literature (Westbrock and Fabian 2010; Hall 2013; Davies-Hoffman et al. 2013; Brecher and Klipfel 2014; Raju 2015; Saunders 2015, and many more) about the disconnect between the increasing importance of pedagogical knowledge and skills in public service academic library positions and the sluggish 
response from LIS schools to this skills demand (see schools' website findings in the next paragraph), it is not surprising that a knowledge and skills void exists in academic libraries, even at the senior levels at which the job advertisements are crafted. This finding is a direct result of the historical neglect by LIS schools, in South Africa as it is internationally, of pedagogical training of graduates in their professional preparation for the work place being a formally recognized requirement.

In May 2016, an examination of the curriculum pages of the websites of the nine active LIS schools in South Africa based at the Universities of Pretoria, Western Cape, KwaZuluNatal, South Africa, Zululand, Limpopo, Fort Hare, Walter Sisulu and Cape Town revealed a marked absence of evidence of required modules in teaching and learning. It is quite possible that pedagogical skills training is embedded in generic course titles such as Reference, User Education, etc. - but the absence of teaching and learning as a discrete skills set in the course offerings of these schools is in itself an indication of neglect of this knowledge and skills set in South African LIS schools' curricula (as is common internationally as well). An exception is one of the universities which offers modules in 'Teaching and Learning for LIS Professionals' and 'Research Librarianship', both of which directly address knowledge and skills development in teaching and instruction in academic libraries - but these are not 'required' or compulsory modules; they are specialization electives in a senior degree and are not offered as required education and training in the professional programme of the school in its preparation of new graduates for the work place. Hence in South Africa, as in other parts of the world, librarians in public service academic library positions thrust into teaching roles as a result of 'disruptive innovations' (Shank and Bell 2011, 105) in the form of evolving digital technologies, have had little choice but to resort to on-the-job training and other CPD avenues. As pointed out by Hall (2013), Hensley (2015) and others, however, this option does not go deep enough to allow the instruction librarian to fully address the realities of classroom needs. Among the 108 job advertisements analyzed, two of these, as part of requirements for the job, requested a 'Teaching or training qualification'. Implicit in this is the realization by some employers that sound pedagogical grounding is required to fulfill teaching roles in academic libraries and not simply on-the-job-training. Whether this positive finding becomes a regular trend in the future remains to be seen.

For Bell and Shank (Bell and Shank 2004, 373; Shank and Bell 2011, 105-107), a blended academic librarian 'combines the traditional skill set of librarianship with the information technologist's hardware/software skills, and the instructional or educational designer's ability to apply technology appropriately in the teaching-learning process' in response to 'disruptive 
innovations' resulting from technology developments in the digital age impacting on academic library services. Drawing from this concept of blending skills across relevant disciplines, for data mining purposes in the content analysis of the 108 academic library job advertisements, the researcher created a category called Blending LIS skills with IT and pedagogical skills (see Table 2) to cluster skills such as educational technology skills, instructional technology skills, research related technology skills, etc. Here too the frequency counts are very meagre or nil (see Table 2). This is an indication that Bell and Shank's (2004, 372-373) evolving concept of academic librarians embracing the 'blended librarian' role to 'more proactively advance their integration into the teaching and learning process' of the academic enterprise and thus avoid being marginalized in an environment of 'tumultuous change' caused by disruptive technologies, is yet to take form in South African academic libraries. That is, the blending of cross-disciplinary skills in a pluralist information environment such as an academic library where the disciplines of LIS, education and information technology intersect, is yet to reflect itself in academic library job advertisements and hence in its recruiting processes. This is likely not to be just a South African phenomenon as the literature abounds in debate about the librarian’s ‘teacher identity'.

Figure 1 summarizes, by knowledge and skills categories, the uneven frequency counts from Table 2 which depicted the data from the job advertisement content analysis showing the lower frequency counts for pedagogy related categories compared to higher frequency counts for generic, library and research related instruction and training categories. Shank and Bell $(2011,106)$ admit that 'while the teaching role of the librarian has been developing and evolving over the past century, it has not altogether been completely agreed upon'. It would seem that their evolving blended librarian framework is aimed at proactively consolidating this process (Shank and Bell 2011). This article found the aspect of their work relating to the concepts of 'disruptive innovations' and blending of LIS, IT and pedagogical skills to respond to technology disruptions in a highly digitized higher education environment very useful. The wider literature (Walter 2008; Hall 2013; Hensley 2015) also raises the issue of the academic librarian's 'teacher identity' - both from the point of view of academic librarians themselves as well as from the perspective of students, academic staff and other university constituencies.

Based on the findings of this study from the literature reviewed and the analysis of the job advertisements, supported by selected findings from the online survey of academic librarians in South Africa as well as from an examination of the websites of LIS schools, it would appear that despite their increasing teaching responsibilities, as long as academic librarians are not properly grounded in pedagogical training through formal LIS school professional preparation, 
they will not be in a position to 'express their full "teacher identity"، (Hensley 2015, 321) to themselves and to the university community confidently. Their under-preparedness and lack of confidence in carrying out their teaching roles and continued dependence on CPD to develop their pedagogical competencies, lie behind this assertion. Hence because of this underpreparedness and lack of confidence, the question whether 'to teach or not to teach?', will persist in the mindsets of librarians and also in that of others - and so perpetuate the academic librarian’s ‘teacher identity’ problem.

\section{CONCLUSIONS AND RECOMMENDATION}

In response to the research question asking what are the pedagogical competency requirements of the academic librarian in South Africa in the current digital age, this article, based on the findings and discussion presented, comes to the following conclusions: 'Disruptive innovations' resulting from rapidly evolving digital technologies in South Africa, as in other parts of the world, have increased and will continue to increase the teaching responsibilities of public service position academic librarians working in the digital age. While these academic librarians have enthusiastically embraced the teaching roles thrust upon them, the LIS schools in South Africa have not prepared librarians to assume these roles with the full pedagogical breadth and depth (as reflected in the pedagogical competency list presented in Table 2). The curricula lack fundamental pedagogical grounding in teaching and learning which seems to be part of a global disconnect between the increasing teaching responsibilities of academic librarians and a sluggish response from LIS schools to this demand. While instruction librarians have relied on on-the-job training and other CPD opportunities to grow their pedagogical skills, this less than satisfactory situation allows doubts about the academic librarian's 'teacher identity' to persist.

Bell and Shank’s (Bell and Shank 2004; Shank and Bell 2011: 106) suggestion about the blending of traditional librarian skills with IT and pedagogical skills in a pluralist information environment such as that of the university library to proactively advance the integration of academic librarians in the wider teaching and learning process of the academy and so mitigate the marginalization of academic librarians in the face of 'disruptive innovations', is a useful one. However, further research needs to be undertaken to ascertain how sustainable Bell and Shank’s (Bell and Shank 2004; Shank and Bell 2011) evolving concepts are in taking forward the pedagogical role of the academic librarian. This study, which was part of a wider LIS competency study, used job advertisements as its primary source of empirical data and a review of literature, supported by relevant data from an online generic survey of academic libraries in 
Figure 1: Pedagogical competency requirements of the academic librarian in the digital higher education environment $(\mathrm{N}=304)$

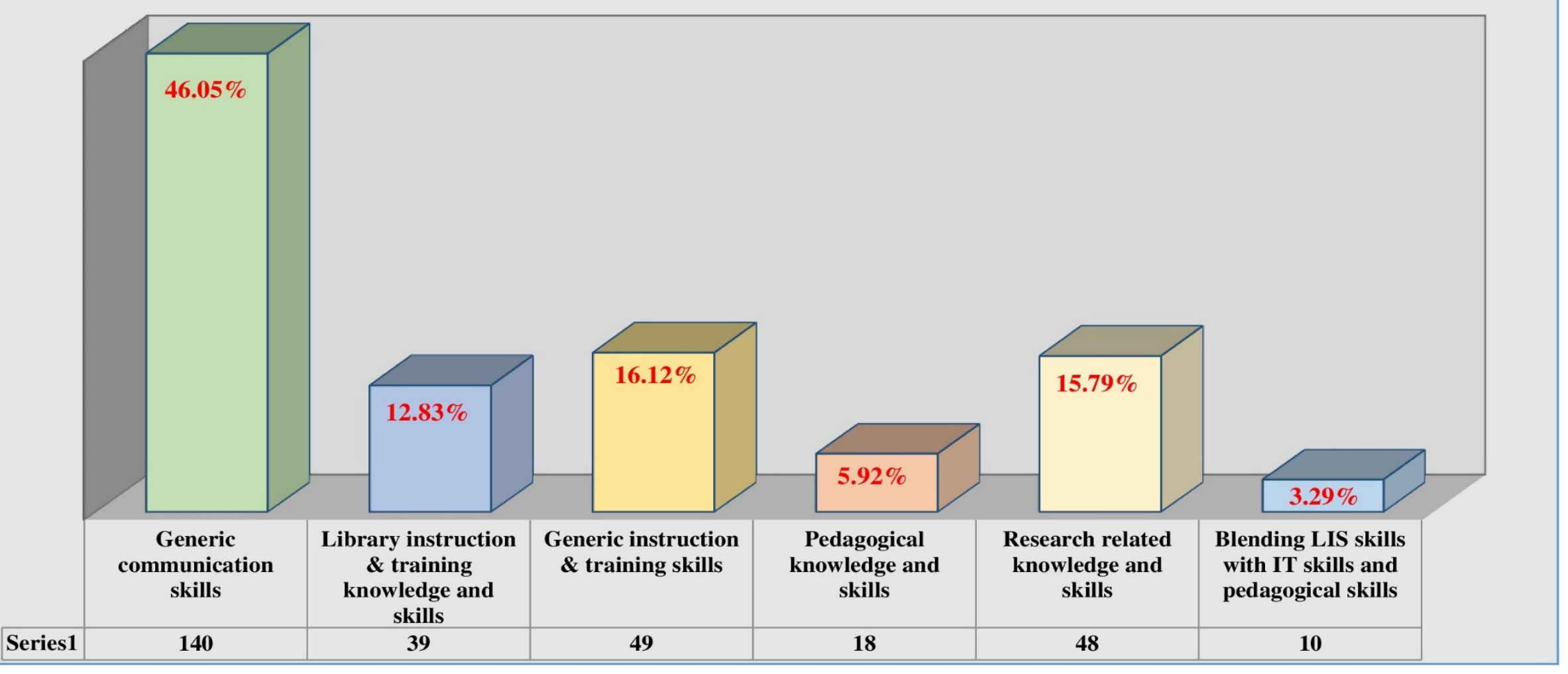


South Africa as well as by an examination of the websites of LIS schools in South Africa (many of which were not detailed enough or recently updated). This article, therefore, recommends that for a fuller picture of findings gleaned from this study, a detailed qualitative study be undertaken, using a phenomenological design involving interviews with LIS schools, personal narratives of academic librarians and other relevant university stakeholders (such as students and academics) and a detailed study of course descriptions of LIS professional programmes in South Africa. This article offers a baseline South African perspective on these issues which have been dominated in the literature by studies from the global north, particularly the USA.

\section{REFERENCES}

ACRL see Association of College and Research Libraries.

Association of College and Research Libraries. 2008. Standards for proficiencies for instruction librarians and coordinators: A practical guide. Chicago: ACRL. http://www.ala.org/acrl/sites/ala.org.acrl/ files/content/standards/profstandards.pdf. (accessed 6 September 2016).

Baro, E. E. and V. Z. Godfrey. 2015. Web 2.0, Library 2.0, Librarian 2.0 and the challenges for librarians in Africa: A review of current literature. International Journal of Information Technology and Library Science 4(1): 1-16.

Bell, S. J. and J. Shank. 2004. The blended librarian: A blueprint for redefining the teaching and learning role of academic librarians. College \& Research Libraries News July/August: 372-375.

Biesta, G. 2010. Pragmatism and the philosophical foundations of mixed methods research. In Sage handbook of mixed methods in social \& behavioral research. ed. A. Tashakkori and C. Teddlie, 95118. $2^{\text {nd }}$ Edition. Los Angeles: Sage.

Brecher, D. and K. M. Klipfel. 2014. Education training for instruction librarians. Communication in Information Literacy 8(1): 43-49.

Chiware, E. R. T. 2007. Training librarians for the digital age in African university libraries. Paper presented at the Satellite Meeting: IT (Information Technology) and Research in African University Libraries: Present and Future Trends of the IFLA (International Federation of Library Associations and Institutions) World Library and Information Congress, Durban, South Africa, August 2007. http://www.ifla.org/IV/ifla73/satellite1Programme-en.pdf. (accessed 14 July 2016).

Corrall, S. 2010. Educating the academic librarian as a blended professional: A review and case study. http://ira.lib.polyu.edu.hk/bitstream/10397/1731/1/Session1A_Corrall.pdf. (accessed 15 September 2016).

Creswell, J. W. 2014. Research design: Qualitative, quantitative and mixed methods approaches. $4^{\text {th }}$ Edition. Los Angeles: Sage.

Davies-Hoffman, K., B. Alvarez, M. Costello and D. Emerson. 2013. Keeping pace with information literacy instruction for the real world: Will MLS programs wake up and smell the LILACs. Communication in Information Literacy 7(1): 9-23.

De Bruyn, T. 2007. Questioning the focus of LIS education. Journal of Education for Library and Information Science 48(2): 108-115.

Hall, R. A. 2013. Beyond the job ad: Employers and library instruction. College \& Research Libraries 71(1): 24-38.

Hensley, M. K. 2015. Improving LIS education in teaching librarians to teach. http://www.ala.org/acrl/sites/ 
ala.org.acrl/files/content/conferences/confsandpreconfs/2015/Hensley.pdf. (accessed 4 September 2016).

Mathews, J. M. and H. Pardue. 2009. The presence of IT skills sets in librarian position announcements. College \& Research Libraries 70(3): 250-257.

Miller, M. J. 2007. Information communication technology infusion in $21^{\text {st }}$ century librarianship: A proposal for a blended core course. Journal of Education for Library and Information Science 48(3): 202-217.

Musangi, P. S. 2015. Library 2.0 and the changing landscape of information services in academic libraries in Kenya. International Journal of Library and Information Science 7(10): 183-187. DOI:10.5897/IJLIS2014.0492.

Neuman, W. L. 2006. Social research methods: Qualitative and quantitative approaches. $6^{\text {th }}$ Edition. Boston: Pearson.

Orme, V. 2008. You will be ...: A study of job advertisements to determine employers' requirements for LIS professionals in the UK in 2007. Library Review 57(8): 619-633. DOI:10.1108/00242530810899595.

Punch, K. F. 2014. Introduction to social research: Quantitative \& qualitative approaches. $3^{\text {rd }}$ Edition. Los Angeles: Sage.

Raju, J. 2014. Knowledge and skills for the digital era academic library. The Journal of Academic Librarianship 40: 163-170. DOI:10.1016/j.acalib.2014.02.007.

Raju, J. 2015. Curriculum content and delivery: South African LIS education responses to a changing information landscape. In LIS education and research in a dynamic information landscape, ed. C. Bitso and R. Raju, 21-30. Cape Town: University of Cape Town Libraries. DOI: http://dx.doi.org/ 10.15641/0-7992-2526-6.

Raju, J. 2016. Core competencies in LIS education: Professional, generic and personal competencies for the higher education LIS sector. Paper presented at the World Library and Information Congress $82^{\text {nd }}$ IFLA General Conference and Assembly Satellite Meeting Co-organized by the Section on Education and Training and Section on Library Theory and Research, The Conference Centre at OCLC, Dublin, Ohio, USA, 10 August 2016. http://people.ischool.illinois.edu/ weech/IFLA/XX\%20XXX--16\%20IFLA-Satellite.pdf (2 September 2016).

Riley-Huff, D. A. and J. M. Rholes. 2011. Librarians and technology skills acquisition: Issues and perspectives. Information Technology in Libraries 30(3): 129-140.

Saunders, L. 2015. Education for instruction: A review of LIS education syllabi. The Reference Librarian 56: $1-21$.

Shank, J. D. 2006. The blended librarian: A job announcement analysis of the newly emerging position of Instructional Design Librarian. College \& Research Libraries 67(6): 515-524.

Shank, J. D. and S. Bell. 2011. Blended librarianship: [Re]envisioning the role of librarian as educator in the digital information age. Reference \& User Services Quarterly 51(2): 105-110.

Sinclair, B. 2009. The blended librarian in the learning commons: New skills for the blended librarian. College \& Research Libraries News 70(9): 504-516.

Shongwe, M. S. 2015. The information technology influence on LIS job descriptions in South Africa. Information Technology for Development 21(2): 196-204.

Walter, S. 2008. Librarians as teachers: A qualitative enquiry into professional identity. College \& Research Libraries 69(1): 51-71.

Westbrock, T. and S. Fabian. 2010. Proficiencies for instruction librarians: Is there still a disconnect between professional education and professional responsibilities? College \& Research Libraries 71(6): 569-590. 